\title{
The vitamin D status of East Indian Punjabi immigrants to Canada
}

\author{
By R. S. GIBSON ${ }^{1}$, G. S. BINDRA ${ }^{1}$, P. NIZAN ${ }^{2}$ AND H. H. DRAPER ${ }^{2}$ \\ ${ }^{1}$ Applied Human Nutrition, Department of Family Studies and ${ }^{2}$ Department of Nutritional \\ Sciences, University of Guelph, Guelph, Ontario N1G 2W1, Canada
}

(Received 15 December 1986 - Accepted 10 February 1987)

\begin{abstract}
1. Serum 25-hydroxyvitamin D (25-OHD), calcium and alkaline phosphatase (EC 3.1.3.1) levels and vitamin $D$ intakes (from $3 \mathrm{~d}$ weighed dietary records) were determined in a cohort of fifty-nine male East Indian Punjabi immigrants (37.7 (SD 10.5) years) and fifty-four females (33.3 (SD 7.4) years).

2. Females had somewhat lower mean serum $25-\mathrm{OHD}$ levels $(12.3$ (SD $5 \cdot 0) v .14 .2(\mathrm{SD} 5 \cdot 1) \mathrm{ng} / \mathrm{ml}, P<0.05)$ and serum Ca levels $(88($ SD 8$)$ v. 91 (SD 6) $\mathrm{mg} / \mathrm{l})$ than males $(P<0.05)$ whereas serum alkaline phosphatase values (males 167 (SD 63), females 169 (SD 43) IU/l) and dietary vitamin D intakes (males 3.5 (SD 1.8), females 3.3 (SD 2.0) $\mu \mathrm{g} / \mathrm{d})$ were similar.

3. $22 \%$ of the females and $12 \%$ of the males had serum $25-\mathrm{OHD}$ levels below $9.0 \mathrm{ng} / \mathrm{ml}$ but none had serum 25-OHD levels within the range associated with clinically overt disease.

4. In the males, serum $25-\mathrm{OHD}$ levels were negatively correlated with dietary fibre intakes $(\mathrm{g} / \mathrm{d} ; r-0 \cdot 29$; $P<0.05$ ).

5. Multiple-regression analysis indicated that log serum 25-OHD levels were not related to dietary vitamin D intakes. Instead they were associated with sex and dietary fibre intakes $(\mathrm{g} / \mathrm{MJ})(F 3.71 ; P=0.03)$. These two variables explained $8 \%$ of the variance.
\end{abstract}

Biochemical and in some cases clinical deficiencies of vitamin D have been reported amongst the Asian community in the UK (Wills et al. 1972; Hunt et al. 1976; Stephens et al. 1981). The major factors implicated in the etiology of Asian vitamin D deficiency are low dietary intakes and limited endogenous skin synthesis of vitamin D (Hunt et al. 1976). Some investigators, however, have suggested that high intakes of dietary fibre or phytate, or both, arising from the frequent consumption of wholewheat chapattis may also play a role (Wills et al. 1972; Reinhold, 1976). The relative importance and precise mechanism of these antinutrients in the etiology of Asian vitamin D deficiency is unclear.

North American East Indian Punjabis who adhere to traditional Eastern dietary patterns and cultural habits may also be at risk of sub-optimal vitamin D status. Many are Sikhs, an Asian religious group shown in the UK studies to have the highest consumption of chapatti flour and a relatively low vitamin D intake (Hunt et al. 1976). To date, however, the vitamin D status of Punjabis in North America has not been investigated. Consequently, as part of a comprehensive nutrition survey, we have assessed the vitamin D status of a group of Canadian East Indian Punjabis using dietary and biochemical assessment methods.

\section{METHODS}

\section{Subjects}

Details of the subjects and collection of the dietary information for the present study have been described earlier (Bindra et al. 1986). Briefly, fifty-nine male East Indian Punjabi subjects (mean age $37 \cdot 7$ (SD 10.5) years) and fifty-four females (mean age $33 \cdot 3$ (sD 7.4) years) were recruited from the East Indian communities of Guelph and Kitchener-Waterloo, Ontario, after completion of written consent. The majority of the subjects were from Punjabi families who had emigrated from India during 1970-5. All except five were Sikhs and all were consuming self-selected diets. The study protocol was approved by the Human Ethics Committee of the University of Guelph. 
The socio-economic index (SEI) of the subjects was determined from the husband's occupation according to the scale of Blishen \& McRoberts (1976). The SEI values ranged from 26.5 to 74.2 (mean $45 \cdot 8$ ) for males and from 26.5 to 74.2 for females (mean 44.0 ), mean values corresponding to the skilled labour class.

All the subjects were apparently healthy with no evidence of any disorders of calcium homeostasis. None were taking barbiturates or hydantoin medications.

\section{Dietary assessment}

Subjects completed weighed dietary records on two consecutive weekdays and one weekend day, using dietary scales (Model no. 1440; Hanson, Shubuta, MS) and bilingual food diaries. Records were checked on completion by a Punjabi nutritionist (G.S.B.). All foods and beverages consumed were recorded and recipes were obtained for all prepared food items. Vitamin and mineral supplement usage was also recorded. Daily vitamin D intakes, frequency and average intake $(\mathrm{g})$ of grain products, and major food sources of vitamin $\mathrm{D}$ were calculated from the coded $3 \mathrm{~d}$ records using a computerized nutrient data bank based on the Condensed Canadian Nutrient File (Health and Welfare Canada, 1984). The latter was extended to include appropriate values for ethnic foods obtained from food composition tables (Gopalan et al. 1974; Paul \& Southgate, 1978) and the literature (Wharton et al. 1983). Findings relating to energy, protein, dietary fibre, $\mathrm{Ca}$ and $\mathrm{P}$ intakes have been published elsewhere (Bindra \& Gibson, 1986).

\section{Biochemical assessment}

Fasting blood samples were drawn via peripheral venipuncture from all the subjects during the months of June to August in 1983 and 1984 to minimize any seasonal effect on serum 25 -hydroxyvitamin D (25-OHD) levels. Serum was promptly separated and frozen at $-76^{\circ}$ before assay. Serum was extracted using the high-performance liquid chromatography (HPLC) grade acetonitrile Sep-Pak procedure described by Fraher et al. (1983) after the addition of purified $25\left[26,27-\right.$ methyl $\left.-{ }^{3} \mathrm{H}\right]$ hydroxyvitamin $\mathrm{D}$ (10000 disintegrations $/ \mathrm{min}$ in $10 \mu \mathrm{l}$ ethanol) to determine extraction losses. Serum 25-OHD was separated by HPLC using a Zorbax-Sil column developed with hexane-isopropanol-methanol ( $90: 5: 5$ by vol., $2.0 \mathrm{ml} / \mathrm{min}$ ) and a $254 \mathrm{~mm}$ detector. Overall mean recovery of tritiated 25-OHD was 74.4 (SD 8.2) \% ( $n$ 109). This procedure does not separate the 25-hydroxylated derivatives of vitamins $\mathrm{D}_{2}$ and $\mathrm{D}_{3}$, and hence the values are reported as total 25-OHD. Serum 25-OHD was estimated by a competitive-protein-binding method modified from Lambert et al. (1981). Details of this method have been described by Gibson et al. $(1986 a)$. The intra- and interassay coefficients of variation were 12.3 and $9.6 \%(n 8)$ respectively. A portion of a standard reference sample of serum was included in each assay.

Serum Ca was determined using a $\mathrm{Ca}$ analyser (Model 940; Corning, New York). Alkaline phosphatase (EC 3.1.3.1) was determined using the method of Babson et al. (1966). Serial replications of a quality-control serum (Labtrol Dade Chemical Co., Miami, Fl.) were used to check on the accuracy and reproducibility of the $\mathrm{Ca}$ and alkaline phosphatase methods. Biochemical results were not included for women known to be either pregnant, lactating or taking oral contraceptive agents.

\section{Statistical analysis}

Serum 25-OHD followed a skewed distribution which was normalized by logarithmic transformation. Student's $t$ tests for non-paired values were used to compare the dietary and biochemical variables between males and females and those subjects of each sex with serum $25-\mathrm{OHD}$ levels $<$ and $>9 \mathrm{ng} / \mathrm{ml}$. Spearman rank correlation coefficients were calculated to assess relations between the calculated dietary intakes (per d; per MJ) and serum 


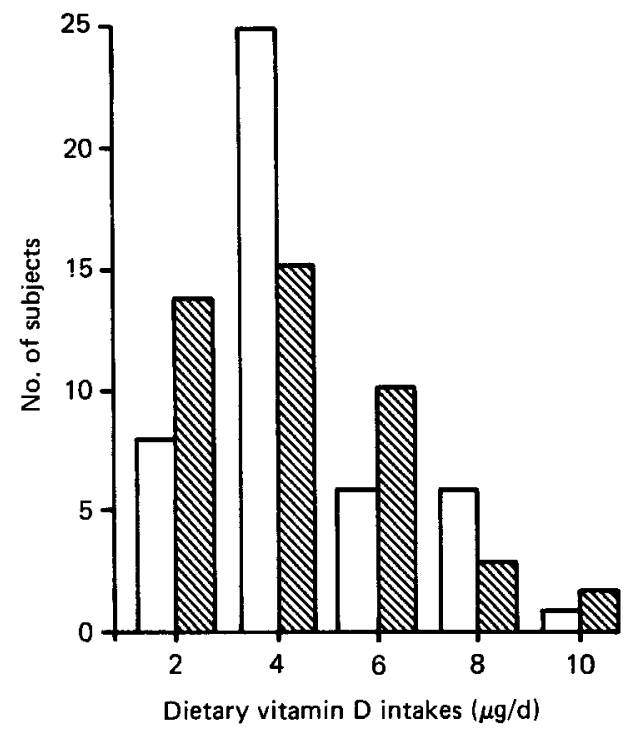

Fig. 1. Frequency distribution of average dietary intakes of vitamin D calculated from $3 \mathrm{~d}$ weighed food records for Canadian Punjabis. ( $\square$ ), Males ( $n$ 47); (\$), females ( $n$ 44).

Table 1. Mean daily vitamin D, calcium, phosphorus and dietary fibre intakes of male and female Canadian Punjabis

(Mean values and standard deviations for forty-seven men and forty-four women)

\begin{tabular}{|c|c|c|c|c|}
\hline & \multicolumn{2}{|c|}{ Males } & \multicolumn{2}{|c|}{ Females } \\
\hline & Mean & SD & Mean & SD \\
\hline $\begin{array}{l}\text { Vitamin D intake: } \\
\mu \mathrm{g} / \mathrm{d} \\
\mu \mathrm{g} / \mathrm{MJ} \\
\mu \mathrm{g} / \mathrm{Mcal}\end{array}$ & $\begin{array}{l}3 \cdot 5 \\
0 \cdot 35 \\
1 \cdot 5\end{array}$ & $\begin{array}{l}1 \cdot 8 \\
0 \cdot 15 \\
0 \cdot 6\end{array}$ & $\begin{array}{l}3 \cdot 3 \\
0 \cdot 45 \\
1.9\end{array}$ & $\begin{array}{l}2 \cdot 0 \\
0 \cdot 24 \\
1 \cdot 0\end{array}$ \\
\hline $\begin{array}{l}\mathrm{Ca}(\mathrm{mg} / \mathrm{d}) \\
\mathrm{P}(\mathrm{mg} / \mathrm{d}) \\
\text { Dietary fibre }(\mathrm{g} / \mathrm{d})\end{array}$ & $\begin{array}{c}990 \\
2034 \\
29 \cdot 3\end{array}$ & $\begin{array}{l}352 \\
543 \\
10 \cdot 6\end{array}$ & $\begin{array}{r}837^{*} \\
1489^{*} \\
23 \cdot 6^{*}\end{array}$ & $\begin{array}{r}335 \\
429 \\
8 \cdot 1\end{array}$ \\
\hline
\end{tabular}

Mean values for females were significantly different from those for males: ${ }^{*} P<0.05$.

$\mathrm{Ca}$, alkaline phosphatase and $\log$ serum 25-OHD. Variables known to be related to serum 25-OHD levels and found to be significantly correlated were used to construct a predictive equation for log serum 25-OHD levels by stepwise multiple-regression analysis.

\section{RESULTS}

Fig. 1 presents the frequency distributions of the mean daily dietary vitamin $D$ intakes of the forty-seven males and forty-four females who completed the dietary records. None of the subjects took pharmaceutical preparations of vitamin D. Mean dietary intakes $(\mu \mathrm{g} / \mathrm{d}$; $\mu \mathrm{g} / \mathrm{MJ}$ ) of vitamin $\mathrm{D}$ for males and females were comparable (Table 1) and above the Canadian Recommended Nutrient Intake (RNI) $(2.5 \mu \mathrm{g} / \mathrm{d})$ (Health and Welfare Canada, 1983). Nevertheless, 23 and $45 \%$ of the males and females respectively, had average dietary 
Table 2. Percentage contribution of nine food groups to the vitamin $D$ and dietary fibre intakes of Canadian Punjabis

\begin{tabular}{lrr}
\hline & $\begin{array}{c}\text { Vitamin } \\
\text { D }\end{array}$ & $\begin{array}{c}\text { Dietary } \\
\text { fibre }\end{array}$ \\
\hline Milk and milk products & $84 \cdot 2$ & $0 \cdot 1$ \\
Meat, poultry and fish & $0 \cdot 6$ & $0 \cdot 2$ \\
Eggs, legumes and nuts & $10 \cdot 1$ & $6 \cdot 4$ \\
Fruits and fruit juices & $0 \cdot 0$ & $10 \cdot 2$ \\
Vegetables & $0 \cdot 0$ & $23 \cdot 9$ \\
Bread and cereals & $1 \cdot 8$ & $55 \cdot 5$ \\
Fats and oils & $3 \cdot 0$ & $0 \cdot 0$ \\
Sugars, sweets & $0 \cdot 3$ & $0 \cdot 1$ \\
Beverages, alcohol and & $0 \cdot 0$ & $3 \cdot 6$ \\
miscellaneous & & \\
\hline
\end{tabular}

Table 3. Serum 25-hydroxyvitamin D (25-OHD), calcium and alkaline phosphatase (EC 3.1.3.1) levels of male and female Canadian Punjabis

(Mean values with $95 \%$ confidence limits in parentheses, except 25-OHD where the geometric mean is given, for fifty-eight males and fifty-one females)

\begin{tabular}{lcc}
\hline & Males & Females \\
\hline Serum 25-OHD (ng/ml) & $13 \cdot 5(12 \cdot 4-14 \cdot 6)$ & $11 \cdot 4^{*}(10 \cdot 2-12 \cdot 7)$ \\
Serum Ca (mg/l) & $91(89-93)$ & $88^{*}(86-90)$ \\
Serum alkaline phosphatase (IU/l) & $169(157-180)$ & $167(150-184)$ \\
\hline
\end{tabular}

* Mean values for females were significantly different from those for males: $* P<0.05$.

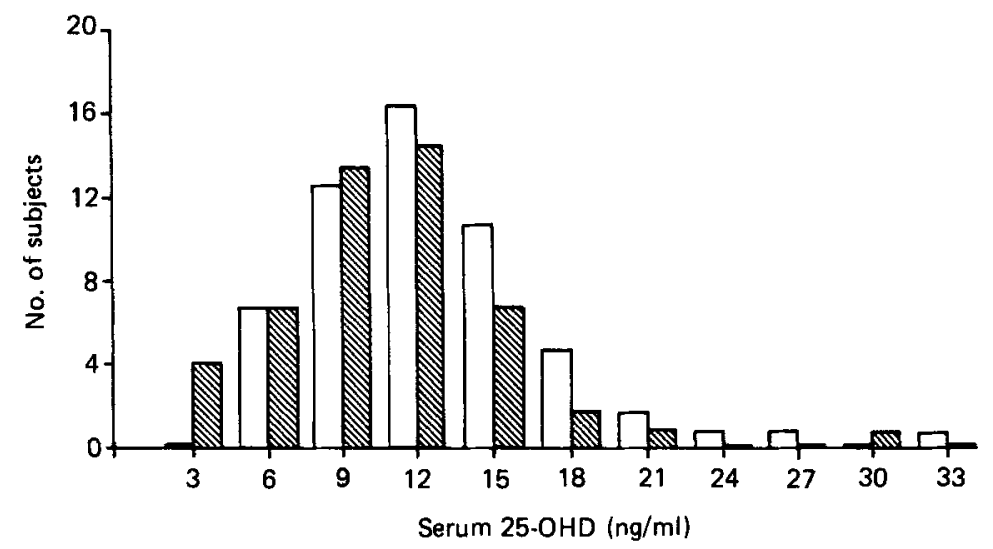

Fig. 2. Frequency distribution of serum 25-hydroxyvitamin D (25-OHD) levels of Canadian Punjabis.

(D) Males ( $n 58)(\mathbb{\$})$, females ( 51$)$.

vitamin D intakes below the RNI. Only $18 \%$ of the males and $24 \%$ of the females were 'at risk' of deficiency according to the probability approach of Anderson et al. (1982). Milk and milk products were the major food sources of both dietary vitamin $\mathrm{D}$ and $\mathrm{Ca}$ for the study group (Table 2). Hence it is not surprising that dietary intakes of vitamin $\mathrm{D}$ and $\mathrm{Ca}$ were positively correlated (per d: $r 0.78, P<0.001$; per MJ : $r 0.64, P<0.001$ ).

Females had lower mean serum 25-OHD and serum $\mathrm{Ca}$ levels $(P<0.05)$ than males 
whereas mean serum alkaline phosphatase values were similar for the males and females (Table 3). Of the males, $12 \%$ compared with $22 \%$ of the females had serum $25-$ OHD levels less than $9.0 \mathrm{ng} / \mathrm{ml}$ (Fig. 2). Of these, only $4 \%$ had concomitant low serum Ca (i.e. $<85$ $\mathrm{mg} / \mathrm{l})$ and none had high alkaline phosphatase activity (>350 IU/l). One subject with a markedly high alkaline phosphatase activity ( $>460 \mathrm{IU} / 1)$ also had a high serum 25-OHD level $(>32.7 \mathrm{ng} / \mathrm{ml})$.

There were no significant differences in mean energy, protein, dietary fibre, vitamin $D$, $\mathrm{Ca}$ or P intakes (per d; per MJ) between subjects with serum 25-OHD levels $<$ and $>9 \mathrm{ng}$ / $\mathrm{ml}$ among either males or females. In the males, log serum 25-OHD levels were negatively associated with dietary fibre intakes on a $\mathrm{g} / \mathrm{d}$ basis $(r-0.29 ; P<0.05)$ and on a $\mathrm{g} / \mathrm{MJ}$ basis, although the latter relation was not significant $(P>0.05)$.

Stepwise multiple regression analysis indicated that the log serum 25-OHD levels were not related to dietary vitamin D intakes $(\mu \mathrm{g} / \mathrm{d}$ or $\mu \mathrm{g} / \mathrm{MJ})$ or age, but to sex and dietary fibre intakes $(\mathrm{g} / \mathrm{MJ})(F 3 \cdot 71 ; P=0.03)$. However, these two variables explained only $8.0 \%$ of the variance.

\section{DISCUSSION}

Our findings clearly show that Canadian East Indian Punjabis have lower mean serum 25OHD levels than Caucasian adults of comparable age, sampled at the same time of the year (McLaughlin et al. 1974; Stamp \& Round, 1974; Omdahl et al. 1982). Indeed, the geometric mean serum 25-OHD level for the Punjabi women was significantly $(P=0.0001)$ lower than that reported for Canadian Caucasian post-menopausal, non-institutionalized women living in the same community $(11.4 v .15 .6 \mathrm{ng} / \mathrm{ml}$ ) (Gibson et al. 1986a). Of the Punjabi women, $22 \%$ compared with $9 \%$ of the Canadian Caucasian post-menopausal women had serum 25-OHD levels below the range considered normal for Caucasian adults (Holmes \& Kummerow, 1983).

The serum 25-OHD levels of the Canadian Punjabis studied here were not related to their dietary vitamin $\mathrm{D}$ intakes. This finding is contrary to the positive association observed either between the serum 25-OHD and dietary vitamin D levels of Canadian Caucasian post-menopausal women from the same community (Gibson et al. 1986a) and for adult middle-age British Asians (Hunt et al. 1976).

Instead, log serum 25-OHD levels appeared to be statistically related, although weakly, to the dietary fibre intakes of the Punjabis of the present study, as indicated by (a) a negative correlation between dietary fibre intake and $\log$ serum 25-OHD in the males; and (b) multiple-regression analysis results which indicated that dietary fibre was a significant variable in the equation predicting log serum 25-OHD levels. It accounted, however, for only a small amount of the variance $(5.6 \%)$.

This association is of interest in view of the postulated role of dietary fibre in the etiology of Asian vitamin D deficiency (Wills et al. 1972; Hunt et al. 1976; Reinhold, 1976). Reinhold (1976) suggested that components of dietary fibre could form complexes with bile salts, vitamin D and 25-OHD secreted by the liver, leading to increased faecal excretion of vitamin D. Although the half-life of radio-labelled 25-OHD in the plasma has been reported to be reduced in subjects consuming a high-fibre diet (Batchelor \& Compston, 1983), the amount of 25-OHD secreted in bile has been found to be negligible (Clements et al. 1984). Reduced enterohepatic circulation of this metabolite therefore does not appear to explain the association between a high-fibre intake and low serum 25-OHD levels seen in the present and previous studies.

The mean calculated dietary fibre intakes of the male and female Canadian Punjabis were higher than those reported for the Canadian Caucasian post-menopausal (Gibson et al. $1986 b$ ) and pre-menopausal women, from the same community (Gibson \& Scythes, 1982) 
because the Punjabis regularly consumed wholewheat chapatis enriched with bran. Individual average daily intakes of dietary fibre was calculated from $3 \mathrm{~d}$ weighed dietary records in the present study. This length of time, however, is probably not sufficient to estimate accurately the usual intake of dietary fibre for individuals (Gibson et al. 1985). As a result, errors arising from wide variations in intakes with the same individual (intrasubject variation), as well as random measurement errors, will probably be large in this dietary method. The effect of these errors is always to reduce the absolute value of the correlation coefficient between dietary intakes and biochemical indices (Liu et al. 1978) so that false negative conclusions may be drawn.

In addition, the combined effects of relatively high dietary vitamin D intakes (Table 1), and endogenous skin synthesis of vitamin $D_{3}$ from the solar radiation during the spring period of the present survey, would tend to raise serum 25-OHD concentrations and hence obscure the effect of dietary fibre. In view of these confounding factors, it is surprising that any relation, however weak, between serum 25-OHD and dietary fibre levels, was evident in the present study.

The higher average dietary vitamin D intakes for the Punjabis of the present study (males $3.3 \mu \mathrm{g} / \mathrm{d}$; females $3.5 \mu \mathrm{g} / \mathrm{d}$ ) compared with the British Asians studied by Hunt et al. (1976) $(1.6 \mu \mathrm{g} / \mathrm{d})$ were attributed to their frequent consumption of yoghurt prepared from milk. The latter is fortified with vitamin D in Canada (unlike the UK). Indeed milk and milk products provided the major source of vitamin D for the Canadian Punjabis (Table 2) compared with eggs and margarine for the UK Sikh Asians (Hunt et al. 1976).

Phytic acid, by its interference with $\mathrm{Ca}$ absorption, has also been implicated in vitamin $\mathrm{D}$ deficiency in Asian immigrants in the UK. Unfortunately, average phytic acid intakes could not be calculated from the $3 \mathrm{~d}$ dietary record values because information on phytic acid values for individual foodstuffs is limited. Hence the influence of phytic acid on log serum 24-OHD values of the Punjabis subjects of the present study could not be evaluated.

Instead, an attempt was made to evaluate the simultaneous influence of both dietary fibre and phytic acid levels on the serum 25-OHD levels using regression analysis. The frequency of consumption of grain products and average intake $(\mathrm{g})$ were tested as independent variables in the regression equation because grain products provided the major source of energy $(42.2 \%)$, dietary fibre $(55.5 \%)$ and probably phytic acid. Neither of these two independent variables was significant in the regression equation.

The only other significant independent variable in the regression equation predicting $\log$ serum $25-\mathrm{OH}$ values was sex, accounting for $5 \cdot 1 \%$ of the variance. This association was not related to sex differences in dietary intakes of vitamin $\mathrm{D}$, dietary fibre (per $\mathrm{d}$; per $\mathrm{MJ}$ ) or year of blood sampling. Instead, the lower serum 25-OHD levels in females may reflect a hormonal difference or, alternatively, limited endogenous skin synthesis of vitamin D due to lack of exposure to solar ultraviolet radiation (Fraser, 1983). No information on time spent outside by the subjects was collected.

The finding that serum 25-OHD levels were not statistically related to dietary vitamin D intakes in these Canadian Punjabis is consistent with those of other vitamin D studies of younger adult Caucasians (Stamp \& Round, 1974). In contrast, in older, more housebound Caucasian adults, a positive association between serum 25-OHD and dietary vitamin D levels has been documented (Corless et al. 1975; Omdhal et al. 1982; Gibson et al. $1986 a$ ).

In summary, in the present study log serum 25-OHD levels appeared to be weakly associated with intakes of dietary fibre, and not with dietary vitamin D intakes. Sex was also a significant factor influencing serum 25-OHD levels. A much higher proportion of the female Canadian Punjabis had below normal serum 25-OHD levels, compared with Canadian Caucasian post-menopausal women from the same community. Nevertheless, 
none had levels within the range associated with clinically overt disease. Mean serum 25OHD levels for the Canadian Punjabis were slightly higher than those reported for UK Asians, consonant with their higher average dietary vitamin D intakes and exposure to solar radiation.

\section{REFERENCES}

Anderson, G. H., Peterson, R. D. \& Beaton, G. H. (1982). Nutrition Research 2, 409415.

Babson, A. L., Greeley, S. J., Coleman, C. M. \& Phillips, G. E. (1966). Clinical Chemistry 12, $482-490$.

Batchelor, A. J. \& Compston, J. E. (1983). British Journal of Nutrition 49, 213-216.

Bindra, G. S. \& Gibson, R. S. (1986). Biological Trace Element Research 10, 223-234.

Bindra, G. S., Gibson, R. S. \& Thompson, L. U. (1986). Nutrition Research 6, 475-482.

Blishen, B. R. \& McRoberts, H. A. (1976). Canadian Review of Sociology and Anthropology 13, $71-79$.

Clements, M. R., Chalmers, T. M. \& Fraser, D. R. (1984). Lancet i, 1376-1379.

Corless, D., Boucher, B. J., Beer, M. \& Gupta, S. P. (1975). Lancet i, 1404-1406.

Fraher, L. J., Adami, S., Clemens, T. L., Jones, G. \& O'Riordan, J. L. H. (1983). Clinical Endocrinology 18, $151-165$.

Fraser, D. R. (1983). Lancet i, 969-971.

Gibson, R. S., Draper, H. H., McGirr, L. G., Nizan, P. \& Martinez, O. B. (1986a). Nutrition Research 6, $1179-$ 1187.

Gibson, R. S., Gibson, I. L., \& Kitching, J. (1985). Biological Trace Element Research 8, $79-91$.

Gibson, R. S., Martinez, O. B. \& MacDonald, A. C. (1986 b). Journal of Gerontology 40, 296-302.

Gibson, R. S. \& Scythes, C. A. (1982). British Journal of Nutrition 48, 241-248.

Gopalan, C., Rama Sastri, B. V. \& Balasubramanian, S. C. (1974). Report of the Institute of Nutrition, Indian Council of Medical Research, Hyderabad, India.

Health and Welfare Canada (1983). Recommended Nutrient Intakes for Canadians. Ottawa, Canada: Bureau of Nutritional Sciences, Health Protection Branch.

Health and Welfare Canada (1984). Condensed Canadian Nutrient File. Ottawa, Canada: Department of Health and Welfare.

Holmes, R. P. \& Kummerow, F. A. (1983). Journal of the American College of Nutrition 2, 173-199.

Hunt, S. P., O'Riordan, J. L. H., Windo, J. \& Truswell, A. S. (1976). British Medical Journal ii, 1351-1354.

Lambert, P. W., Deoreo, P. B., Hollis, B. W., Fu, I. Y., Ginsberg, D. J. \& Roos, B. A. (1981). Journal of Laboratory and Clinical Medicine 98, 536-548.

Liu, K., Stoamler, J., Dyer, A., McKeever, J. \& McKeever, P. (1978). Journal of Chronic Diseases 31, 399- 418 .

McLaughlin, M., Fairney, A., Lester, E., Raggatt, P. R., Brown, D. J. \& Wills, M. R. (1974). Lancet i, $536-538$.

Omdahl, J. L., Garry, P. J., Hunsaker, L. A., Hunt, W. A. \& Goodwin, J. S. (1982). American Journal of Clinical Nutrition 36, 1225-1233.

Paul, A. A. \& Southgate, D. A. T. (1978). McCance and Widdowson's The Composition of Foods, 4th ed. London: H.M. Stationery Office.

Reinhold, J. G. (1976). Lancet ii, 1132.

Stamp, T. C. B. \& Round, J. M. (1974). Nature 247, 563-565.

Stephens, W. P., Berry, J. L., Klimiuk, P. S. \& Mawer, E. B. (1981). Lancet ii, 1199-1201.

Wharton, P. A., Eaton, P. M. \& Day, K. C. (1983). Human Nutrition: Applied Nutrition 37 A, 378-402.

Wills, M. R., Phillips, J. B., Day, R. C. \& Bateman, E. C. (1972). Lancet i, 771-773. 